\title{
Tel Aviv: From Patrick Geddes' Utopian Social City to the International City of Late Capitalism
}

\author{
HORACIO SCHWARTZ \\ Technion/Israel Institute of Technology \\ Israel
}

In contemporary society - according to Dennis Potter's dictum - citizens have been transformed into consumers. The shift in social power behind this process is mirrored in the changing shape of the city. Tel Aviv, founded just eighty five years ago, is an extreme example of the interaction between urban conceptions and configurations and dominant social forces.

By means of a schematic section through the history of the city, this paper attempts an assessment of the role of those forces and conceptions - or their absence - in determining the nature and scope of the present transformations of the urban fabric.

Tel-Aviv is an assemblage of past and recent urban utopias, constrained by conditions, scaled down and transformed, but still identifiable and influential. Partly "collision city" and partly "collage city" - in Colin Rowe's terms - its growth, while chronologically continuous, resulted in a fragmented pattern; each district reflecting the urban ideals and historical conditions under which it came into being. Four determinant stages can be detected in the ascent of the city.

\section{THE FIRST SUBURBS}

\section{Neve Zedek, the Hipodamic Grid}

Founded as Jewish cooperative in 1887 with an orthogonal disposition of streets, 6 meters wide, and houses built as a continuous mass on the street line. No hierarchy existed, except for the allocation of larger plots at the edges. It was a blend of western influences in urban layout and local architectural typologies.

\section{The Garden Suburb, Ahuzat Bait}

Its foundation in 1909, marks both the beginning of Tel Aviv as an autonomous urban entity and the first attempt of implementation of the garden suburb concept. Based on an orthogonal grid and a building code imposing recessed front lines and limitations of hight and land coverage, leading to detatched one or two leveled houses. Neoclassical in its architectural spirit, the main street led to the civic monument of the time: the neighbourhood's high school, a landmark of orientalistic architecture.
While this area was absorbed by the expanding commercial downtown and its functions and texture radically changed, Neve Tzedek, after a long period of social and physical decay, is undergoing a process of renewal through gentrification.

\section{UTOPIA NOW: GEDDES' MASTER PLAN OF 1925}

When Scotsman Patrick Geddes, "social evolutionist and city planner," was invited to formulate a Master Plan for Tel Aviv, "the idea of community building had been verywhere in the air" - in Ebenezer Howard's words; having pioneered a "sociological approach to the study of urbanization"and having laid down the groundwork for a new understanding of the city- region relationship, Geddes' philosophy had influenced the very concept and scope of planning through the "idea that social processes and spatial form are intimately related." Geddes' report is pemeated by his anarchist worldview and commitment to the garden city idea, but also by the realization that the layout schemes of previous garden cities could not be applied to an existing and expanding major urban environment. His proposal was an hierarchical system of main streets ("mainways") which defined large urban blocks ("home blocks"), structured by narrow residential streets ("homeways") which, together with pedestrian lanes, led to a public park or enclosed avenue at the core of the "home block," with "playgrounds, tennis courts, rich gardens and orchards." This was to be embodiment of the "Garden Village in the very heart of the city." Geddes describes enthusiastically his vision of a "new type of civic grouping, at once more beautiful and more health giving than any previous form of large community in human annals"... "fruit emblazoned in purple and gold."

During the following decades, implementation of the plan converged with the architectural utopian vision of the Modern Movement and produced a sui generis - perhaps unique urban pattern: the "Bauhaus" district of center-north Tel Aviv, a trove of thousands of modernistic buildings interspersed in the Geddesian urban structure. A new society was the slogan that summerized the spirit of the times and the greater civic interest was the main driving force behind urban formation. 
Tel Aviv was and still is a predominantly a middle class city. Most of its land resources are privatly owned, in a pattern of small plots of about 500Sqm each, thus generating a spatial and social equilibrium evidenced in the urban morphology and the typical "Tel Aviv house," a three or four level apartment building on a discontinuous street facade, a contemporary version of the pavilion street. Workers housing projects were built on state owned land, harmonically integrated in the mass and architectural character. "The white city" as poet Natan Alterman wrote about it. With the first magor cultural complex, the Habima theater and Mann auditorium, this period came to a climax and closure.

\section{THE INSTITUTIONAL PERIOD}

From the fifties on, independence and institutionalization, led to organized and planned new social housing; neighbourhoods were laid out according to the established canons of the European siedlung. While adressing the quantitative parameters of mass housing, the fabric of the city, as elsewhere, was disrupted; this approach reached its peak during the seventies and the eighties in the new northern areas beyond the Yarkon river. The local version of the . Corbusian "city of towers" sprang up as paradoxically, a high middle class, streetless motopia; this magor extention of the city, is not only devoid of the qualities of traditional urban environments, but lacking also in its quantitative parameters: it is the least dense district in the city with the highest proportion of - mostly unused - open spaces. State power, being the dominant social force, guided and informed urban planning. Massive institutional building reached its peak with the Tel Aviv University campus, yet another reflection of the isolated "building in the park" concept.

\section{C.B.D. THE CITY OF THE CORPORATION AND THE CONSUMER}

In the late sixties, the first high school, by then a civic symbol, was demolished and replaced by the first high rise office building, signaling the emergence of private enterprise as the dominant force in the social and physical map of the city. From than on architectural programs and typologies follow the transformation of Tel Aviv into a major financial business and production center and the hub of the metropoli$\tan$ area of nearly two million inhabitants. This radical change in the structure of power and gradual integration of Tel Aviv in the global network of multy national production and marketing, demand a major transformation of the city. This is happening at the expense of the civic dimension of urban life. Perception of the singularity of the existing urban fabric and its capacity to absorb and integrate change, has been apparantly abandoned.

The concept of "Central Business District," is widely and uncritically adopted by urban planners, to the extent that the notion of a multifunctional city center is almost no longer debated. However as the boundary and character of the proposed C.B.D. have shifted along time - pointing perhaps to the inadequacy of the concept - office towers rise at random in the urban scape. The point tower typology also provides a reductive solution to densification of housing areas in the inner city, erasing the existing fabric. While the interplay of corporate power and real estate speculation shapes the urban skyline, social and geographical stratification and urban decay follow, as inevitable counterparts. Through the haphazard drive of market forces a different city replaces the existing one going often against its grain and spirit. Conflict replaces concensus. It is significant that in the last two decades few civic places have been created or renovated by public initiative, since the public domain is increasingly considered a by-product of commercial development; the aridity of some of the non-habitable spaces thus built, is a reflection at the semiotic level of their residual nature, not focused on social interaction.

The present predicament stems also from the receding role of urban design and the reluctancy of planning authorities to excercise their considerable statutory powers beyond the task of moderators. Narrowing of the scope of urban discourse has reduced it to the preservation against development antithesis. Advocacy groups for the preservation of the vast early 20 th century and modern architectural heritage, operate as the main alternative in the absence of an urban policy that establishes qualitative goals, while urban design as a means of acheiving them is conspicously missing.

In 1995 the new modern- eclectic building of the Tel Aviv opera house was inaugurated.

\section{EPILOGUE}

While the first neigbourhoods were the result of democratic urbanism, implemented by citizens and cooperatives, almost without mediation, Geddes' plan and more so the northern district implied adelegation of power to the planner or the planning authority as trustee of the common interest.

Geddes' vision, although centered in the environmental qualities of dwelling, permitted the integration of emerging interests and activities without disruption, in spite of a population increase well beyond the original forecast.

Although not a multi layered historical city, Tel Aviv - the imprint of the aspirations that formed and sustained it. In any urban environment, rediscovery and renewal of its specific ethos should be the foundation of planning policy, manifested in the constant recreation and enrichment of the web of public places, which is the raison d'etre of urban culture: therefore the task of urban design is to create the conditions for a democratic synthesis of the urban texture. In the present phase, the acsent of the post industrial city seems to be in conflict, even in contradiction, with civic realm.

Volker M. Welter of the University of Edinburgh in his study "The Republic of Patrick Geddes" has convincingly compared Geddes' view of the city with that of Plato. Whether Tel Aviv will hold as an embodiment of this world view - even in a restricted sense - or be metamorphosed into another example of the one dimensional city of profit and consumption, speculation and decay, is at the center of the recurrent dilemma faced by architects, urbanists, and most cetainly architectural educators as to their role in society: stage setters or community builders. 